\title{
Effect of Carboxymethylcellulose, $\alpha$-Starch, and Wheat Gluten Incorporated in Diets as Binders on Growth, Feed Efficiency, and Digestive Enzyme Activity of Fingerling Japanese Flounder*
}

\author{
Takeshi Yamamoto and Toshio Akiyama \\ Nutrition Section, Inland Station, National Research Institute of Aquaculture, Tamaki, Mie 519-04, Japan \\ (Received August 18, 1994)
}

\begin{abstract}
A feeding experiment was conducted to examine the effect of several ingredients incorporated in diets as binders on the growth, feed efficiency, and digestive enzymes' activities of fingerling Japanese flounder Paralichthys olivaceus. Carboxymethylcellulose (CMC), gelatinized potato starch ( $\alpha$-starch), and wheat gluten were separately incorporated in flounder diets as binders at the $5 \%$ level. These diets were fed to flounder with an initial mean weight of $15 \mathrm{~g}$ for 4 weeks at $20^{\circ} \mathrm{C}$. Weight gain, feed efficien$\mathrm{cy}$, and protein retention of the fish fed a diet containing CMC were significantly inferior to those of the fish fed diets containing $\alpha$-starch or wheat gluten. Apparent digestibility of protein in the diet containing $\mathrm{CMC}$ was also significantly lower than the diet containing wheat gluten. After the 4-week feeding trial, proteolitic and lipolitic enzyme activities were measured with the homogenates of stomach or intestine. Proteolitic enzymes' activities such as pepsin-like and trypsin-like were lower in the fish fed the diet containing CMC than those in the fish fed the diets containing $\alpha$-starch or wheat gluten, and especially trypsin-like activities at 4 to 12 hours after feeding were significantly lower. These results suggest that $\alpha$-starch and wheat gluten are suitable as binders for fingerling flounder diets compared with CMC because CMC inhibits the proteolitic enzymes' activities in digestive tracts.
\end{abstract}

Key words: diet, binder, carboxymethylcellulose, wheat gluten, digestive enzyme, flounder

Several kinds of materials are used as binders in fish diets to keep the form and to avoid running out of nutrients. Sodium carboxymethylcellulose (CMC) has been used as one of such binders in fish diets, especially in laboratory experimental diets. Several studies were conducted on the role of CMC as a dietary fiber. Morita et al. reported that the supplementation of $\mathrm{CMC}$ to the diets containing 10 to $30 \%$ dextrin improved the growth and feed efficiency of red sea bream Pagrus major and the optimum level of CMC in the diets increased with the increase of dietary dextrin level. ${ }^{1)}$ Furuichi et al. demonstrated that this improvement by supplemented CMC was caused by the delayed absorptions of dextrin and protein in digestive tracts. ${ }^{2)}$ On the other hand, Shiau et al. reported that more than $6 \%$ supplementation of $\mathrm{CMC}$ in diets reduced the growth and feed efficiency of tilapia Oreochromis niloticus $\times O$. aureus. ${ }^{3,4)}$ They also observed that digestibility coefficients and gastric emptying times decreased as the level of $\mathrm{CMC}$ in the diets increased. ${ }^{3)}$ The reason for the discrepancies in these results has not been elucidated yet and no studies have been done of the effect of dietary CMC on digestive enzyme activity.

In the present study, we examined how CMC, gelatinized potato starch ( $\alpha$-starch), and wheat gluten incorporated in diets as binders affect the growth, feed efficiency, and in vitro activities of digestive enzymes such as pepsin-like in stomach and trypsin-like in intestine of fingerling Japanese flounder Paralichthys olivaceus.

\section{Materials and Methods}

\section{Experimental Diets}

Formulations and proximate analyses of the test diets are shown in Table 1. CMC, $\alpha$-starch, and wheat gluten were individually used as binders in each diet at the $5 \%$ level. Other ingredients were almost identical in all diets ex-

Table 1. Formulations and proximate analyses of the test diets

\begin{tabular}{|c|c|c|c|}
\hline \multirow{2}{*}{$\begin{array}{l}\text { Diet no. } \\
\text { Binder }\end{array}$} & 1 & 2 & 3 \\
\hline & $\mathrm{CMC}^{* 1}$ & $\alpha-\operatorname{Starch}^{* 2}$ & Wheat gluten \\
\hline \multicolumn{4}{|l|}{ Ingredient ( $\%$ wet weight) } \\
\hline White fish meal & 73.0 & 73.0 & 73.0 \\
\hline Pollock visceral oil & 3.1 & 3.1 & 3.1 \\
\hline Dextrin & 7.9 & 3.1 & 7.9 \\
\hline Cellulose & 4.0 & 8.8 & 4.0 \\
\hline Vitamin mix. ${ }^{* 3}$ & 3.0 & 3.0 & 3.0 \\
\hline Mineral mix. ${ }^{*}$ & 3.0 & 3.0 & 3.0 \\
\hline Chromium oxide $(50 \%)^{* 4}$ & 1.0 & 1.0 & 1.0 \\
\hline Binder $\mathrm{CMC}$ & 5.0 & 0 & 0 \\
\hline$\alpha$-Starch & 0 & 5.0 & 0 \\
\hline Wheat gluten & 0 & 0 & 5.0 \\
\hline \multicolumn{4}{|l|}{ Analysis (\% dry weight) } \\
\hline Crude protein $(\mathrm{N} \times 6.25)$ & 45.3 & 45.2 & 48.6 \\
\hline Crude fat & 10.3 & 10.3 & 10.7 \\
\hline Gross energy (kcal/100 g diet) & 422 & 422 & 428 \\
\hline $\begin{array}{l}\text { *1 Sodium carboxymethylcellulose. } \\
\text { * }_{2} \text { Gelatinized potato starch. } \\
\text { * }_{\text {3 }} \text { Sakamoto et al. } \\
\text { * }_{4} \text { Yamanoto } \text { et al. } \\
\text { (5) }\end{array}$ & & & \\
\hline
\end{tabular}


cept dextrin in diet 2 , the level of which was reduced for the supplemented $\alpha$-starch to adjust the total energy level of digestible carbohydrates. White fish meal was used as a protein source to provide approximately $50 \%$ crude protein in the diets and pollock visceral oil was supplemented to provide $10 \%$ crude fat. ${ }^{*}$ Chromium oxide was supplemented as an indicator for the analysis of apparent digestibility of dietary protein. Wheat gluten had approximately $65 \%$ ctude protein, therefore, the crude protein in diet 3 was slightly higher than the other diets. All ingredients were thoroughly mixed and moistened to have approximately $10 \%$ moisture in the diets, and then pelleted in a California pellet mill. The test diets were stored at $-20^{\circ} \mathrm{C}$ until being fed to the fish.

\section{Fish and Feeding Procedures}

Fingerlings of Japanese flounder were transferred from Nansei-cho Fish Seed Center, Mie, Japan. Twenty fish were stocked in a polyvinyl chloride tank $(60 \times 25 \times 35 \mathrm{~cm}$, holding $40 l$ of water) with duplication for each dietary treatment, and temperature-regulated sea water $(20 \pm$ $0.2^{\circ} \mathrm{C}$ ) was supplied at a rate of $1.5 \mathrm{l} / \mathrm{min}$. The fish were fed a commercial flounder diet and were acclimated to the experimental conditions for 2 weeks prior to the feeding trial. In the feeding trial, the test diets were fed to the fish with an initial mean weight of $15.0 \mathrm{~g}$ until satiation by hand twice a day, 6 days a week for 4 weeks. Just before the start of the feeding trial, 10 fish were randomly sacrificed and stored at $-20^{\circ} \mathrm{C}$ for the proximate analyses of the whole body. The fish were weighed every two weeks after being anesthetized with $0.01 \%$ ethyl 3-aminobenzoate methanesulfonic acid. At the end of the feeding trial, 3 fish were randomly sampled from each tank and stored at $-20^{\circ} \mathrm{C}$ for the proximate analyses.

During the feeding trial, feces were collected using for- ceps with small scoops mounted on the tips. The feces were directly picked up with the forceps when they were found in the tanks and pooled by each tank for the analy. sis of apparent digestibility of dietary protein.

After the 4-week feeding trial, the fish were starved for 3 days to completely empty the digestive tracts. Then, the fish were fed the test diets until satiation. At 2, 4, 8, and $12 \mathrm{~h}$ after the feeding, 3 fish from each tank were randomly sacrificed by a blow to the head and stored at $-80^{\circ} \mathrm{C}$ for the analyses of digestive enzymes' activities.

\section{Analytical Methods}

Proximate analyses of the test diets, whole body, and feces, and calculations of the parameters on growth and feed performances were carried out by the methods described in the previous paper.

Fish for the analyses of digestive enzyme activity were dissected, and stomach and intestine including pyloric caeca were respectively collected. The digesta inside them were rinsed with distilled water (DW). Three samples from each tank were pooled to one, so that the activities were assayed with the two pooled samples of the duplicates for each dietary treatment. Enzyme solutions of stomach or intestine were obtained by homogenizing the pooled samples with 5 times $(\% / w)$ of $\mathrm{DW}$, then extracted at $30^{\circ} \mathrm{C}$ for $1 \mathrm{~h}$ and centrifuged at 3,000 rpm for $15 \mathrm{~min}$. The supernatant of the homogenate was used as an enzyme solution and was diluted with an adequate amount of DW at the time for the analyses. Pepsin-like enzyme activity in the stomach was measured according to the method of Anson ${ }^{6}$ using $0.2 \%$ hemoglobin solution of $\mathrm{pH} 1.8$ as substrata. The reaction was performed at $37^{\circ} \mathrm{C}$ for $10 \mathrm{~min}$ and then stopped by adding $5 \%$ trichloroacetic acid (TCA), and the absorbance of TCA soluble fraction was measured at $280 \mathrm{~nm}$. Trypsin-like enzyme activity in intestine was

Table 2. Growth and feed performances of flounder fed diets containing CMC, $\alpha$-starch, and wheat gluten as binders ${ }^{* 1}$

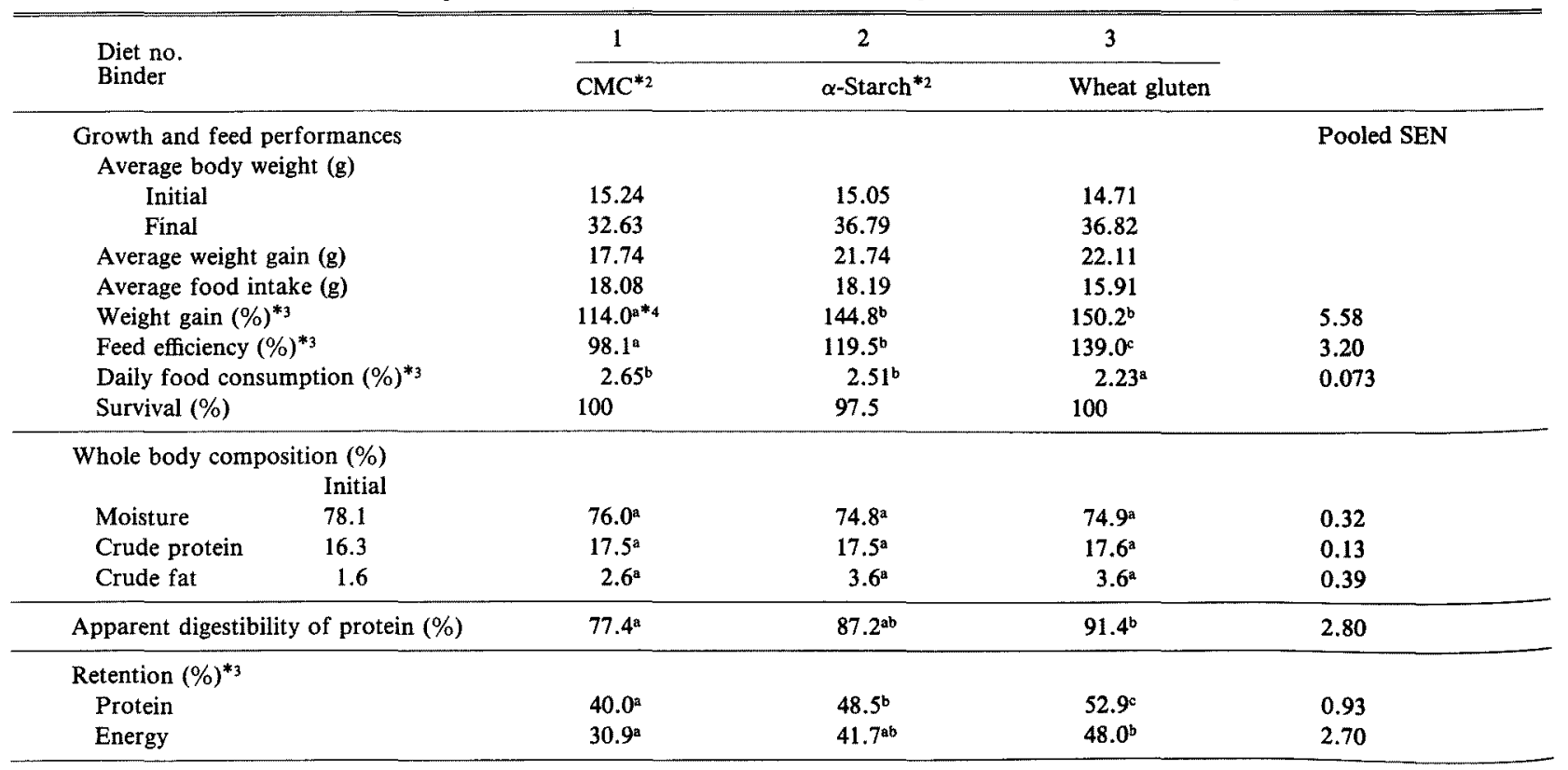

* Average values of duplicate tanks containing 20 fish each reared for 4 weeks at $20^{\circ} \mathrm{C}$.

*2 See the footnote of Table 1 .

*) See the previous paper. . $^{\text {* }}$

$*_{4}$ Values in the same row with the same superscripts are not significantly different at $5 \%$ level. 
measured by the method of Hagihara ${ }^{7)}$ using $0.6 \%$ hemoglobin solution of $\mathrm{pH} 8.0$ as substrata. The reaction was performed at $30^{\circ} \mathrm{C}$ for $10 \mathrm{~min}$ and then stopped by adding $0.44 \mathrm{M} \mathrm{TCA}$, and the reaction products in TCA soluble fraction were determined by the method of Lowry et al ${ }^{87}$ with L-tyrosine as a standard. Lipase activities in stomach or intestine were measured by the method of Yamamura and Ogura) ${ }^{9}$ using $0.1 \mathrm{~m}$ tributirin emulsified with polyvinyl alcohol as substrata. The reaction was performed at $30^{\circ} \mathrm{C}$ for $4 \mathrm{~h}$ and then stopped by adding etheracetone solution. The entire solution was titrated with 0.1 $\mathrm{N} \mathrm{KOH}$ solution. Protein content in the homogenate was determined by the method of Lowry et al. ${ }^{8)}$ with bovine serum albumin as a standard. Specific activity of pepsin-like enzyme was expressed as a change in absorbance at 280 $\mathrm{nm} / 10 \mathrm{~min} / \mathrm{mg}$ enzyme protein, trypsin-like enzyme as $\mu \mathrm{g}$ tyrosine liberated $/ 10 \mathrm{~min} / \mathrm{mg}$ enzyme protein, and lipase as $\mathrm{m} l$ of $0.1 \mathrm{~N} \mathrm{KOH}$ solution consumed for titrating $/ 4 \mathrm{~h} /$ mg enzyme protein.

The parameters of growth and feed performances, and digestive enzyme activities of the duplicates for each treatment were compared using one-way layout analysis of the variance for a significance in the treatments $(p<0.05)$, and Bartlett's test for a uniformity of variances $(p<0.05)$, respectively. After these comparisons, Duncan's new multiple range test was applied to determine significant differences between individual treatments at a significance level of $p<0.05$.

\section{Results}

\section{Growth and Feed Performances}

Weight gain of the fish fed a diet containing $\mathrm{CMC}$ was significantly lower $(p<0.05)$ than the fish fed diets containing $\alpha$-starch or wheat gluten (Table 2). Feed efficiency significantly increased $(p<0.05)$ in the ascending order of CMC, $\alpha$-starch, and wheat gluten. In contrast, food con-

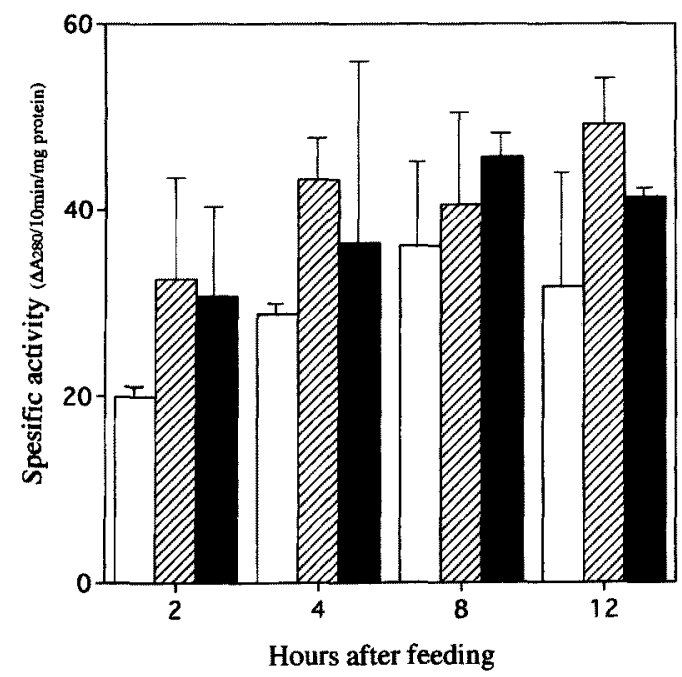

Fig. 1. Effect of CMC, $\alpha$-starch, and wheat gluten incorporated in diets as binders on pepsin-like activity in flounder stomach.

Values are means and standard deviations of two pooled samples (3 fish/sample) of the duplicates for each treatment. No significant differences were detected among the treatments.

ㅁ, CMC; $\square, \alpha$-starch; $\approx$, wheat gluten.

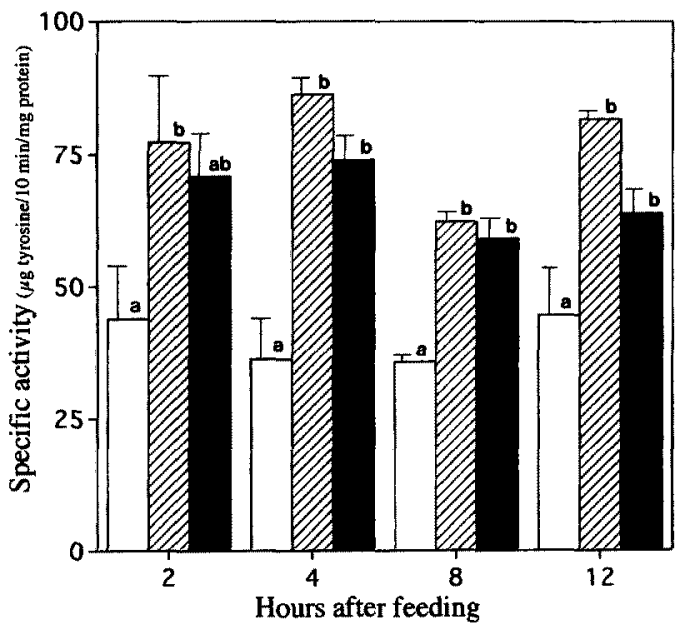

Fig. 2. Effect of CMC, $\alpha$-starch, and wheat gluten incorporated in diets as binders on trypsin-like activity in flounder intestine.

Values are means and standard deviations of two pooled samples ( 3 fish/sample) of the duplicates for each treatment. The mean values with the same superscripts are not significantly different at $5 \%$ level.

Symbols are the same as those in Fig. 1.

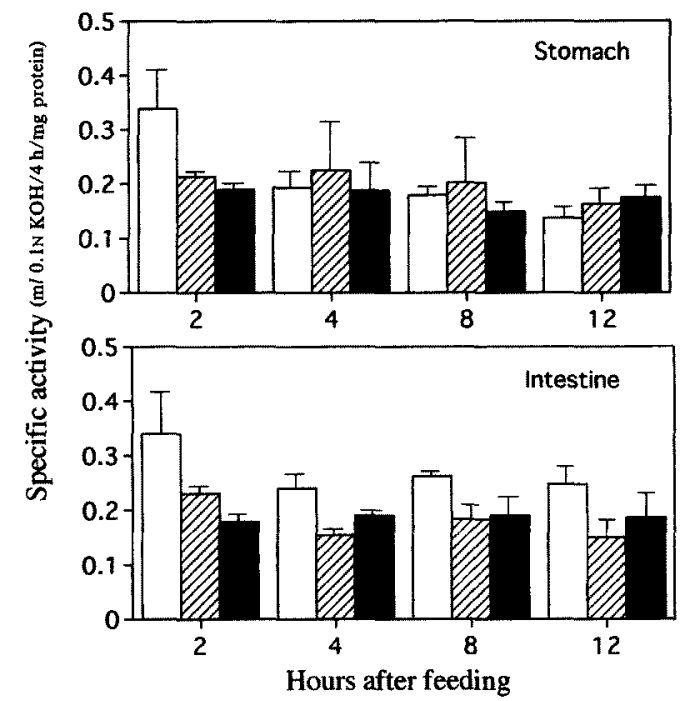

Fig. 3. Effect of $C M C, \alpha$-starch, and wheat gluten incorporated in diets as binders on lipase activity in flounder stomach and intestine.

Values are means and standard deviations of two pooled samples ( $3 \mathrm{fish} /$ sample) of the duplicates for each treatment. No significant differences were detected among the treatments.

Symbols are the same as those in Fig. 1.

sumption rate decreased in this order. Apparent digestibility of dietary protein also increased in this order and a significant difference $(p<0.05)$ was detected between the diets containing $\mathrm{CMC}$ and wheat gluten. No significant differences $(p>0.05)$ were observed in the whole body composition among the treatments, though fat contents in the fish fed the diets containing $\alpha$-starch or wheat gluten were higher than the fish fed the diet containing CMC. Protein retentions were significantly elevated $(p<0.05)$ in the ascending order of CMC, $\alpha$-starch, and wheat gluten. Energy retention of the fish fed the diet containing CMC was significantly lower $(p<0.05)$ than the fish fed the diet 
containing wheat gluten.

\section{Digestive Enzyme Activity}

Pepsin-like activities in the fish fed a diet containing $\mathrm{CMC}$ at 2 to $12 \mathrm{~h}$ after feeding the diet were lower than the fish fed diets containing $\alpha$-starch or wheat gluten, however, significant differences were not detected $(p>0.05)$ (Fig. 1). Trypsin-like activities were significantly lower $(p<0.05)$ at 4 to $12 \mathrm{~h}$ after feeding in the fish fed the diet containing CMC compared with the others (Fig. 2). Lipase activities were rather low and did not vary significantly $(p>0.05)$ among the dietary treatment and the time after feeding (Fig. 3).

\section{Discussion}

In this study, fish fed a diet containing CMC showed inferior weight gain, feed efficiency, and protein digestibility and retention compared to the fish fed diets containing $\alpha$ starch or wheat gluten. Therefore, dietary CMC has proved to have negative effects on fingerling Japanese flounder just as observed by Shiau et al. in tilapia. ${ }^{3,4)}$ However, the immediate causes of these two similar phenomena observed in flounder and tilapia seem to be quite different.

Shiau et al. reported that poorer performances of tilapia fed diets containing more than $6 \%$ level of $\mathrm{CMC}$ were due to the accelerated passage of the digesta from the stomach. ${ }^{3)}$ Similar poor performances were observed in channel catfish Ictalurus punctatus, ${ }^{10)}$ rainbow trout Oncorhynchus mykiss, ${ }^{11)}$ tilapia Oreochromis mossambicus, ${ }^{12)}$ and tilapia O.niloticus ${ }^{13)}$ fed diets containing about $10 \%$ or more of cellulose. In addition, accelerated stomach passages were also observed in the rainbow trout fed diets containing 10 or $20 \%$ of cellulose. ${ }^{11)}$ In contrast, Morita et al. obtained positive effects of CMC in red sea bream fed diets containing 6,9 , and $12 \%$ of $\mathrm{CMC}$ when dietary dextrin levels were 10,20 , and $30 \%$, respectively. ${ }^{1}$ Furuichi et al. further observed the delayed absorptions of the nutrients in the red sea bream fed the diets containing $\mathrm{CMC}$, and presumed that the delay physiologically corresponded to the period for the effective metabolism of the nutrients as energy and/or protein sources. ${ }^{2}$ In their studies on red sea bream, supplemented CMC had replaced the same amount of cellulose in the diets.

As Hilton et al. ${ }^{11)}$ and Bromley and Adkins ${ }^{14)}$ noted in their reports, the presence of non-nutritive fillers including cellulose in fish diets accelerated the evacuation of food from the stomach. ${ }^{15-17)}$ In contrast, water-soluble dietary fibers such as guar gum and pectin were reported to delay stomach passage in mammals ${ }^{18-21}$ due to the increased viscosity of the test diets. ${ }^{22)} \mathrm{CMC}$ is also a water soluble dietary fiber, and is expected to increase the viscosity of the diets and to delay stomach passage in consequence. In tilapia, however, increased CMC in the diets adversely accelerated the stomach passage. ${ }^{3)}$ On the other hand, it could be understood that the stomach passages in the red sea bream fed the diets containing CMC were delayed judging from the delayed absorptions of the nutrients observed by Furuichi et al. $^{2)}$

Thus, the inferior performances in tilapia ${ }^{3)}$ are supposed to be caused by the increase of CMC which might not satis- factorily increase the viscosity of the diets for uncertain reasons and accelerated the stomach passages just like cellulose. In contrast, the improved growth and feed performances in red sea bream reported by Morita et al. ${ }^{11}$ are supposed to be caused both by the supplementation of $\mathrm{CMC}$ which increased the viscosity of the diets and delayed stomach passages as observed in mammals, ${ }^{22)}$ and by the decrease of cellulose which accelerated stomach passages.

In the present study, weight gain and feed efficiency of Japanese flounder fed a diet containing CMC were inferior to those of the fish fed diets containing $\alpha$-starch or wheat gluten as binders. Since wheat gluten and $\alpha$-starch have some nutritional values as protein and/or energy sources, the nutritional value of diet 3 was slightly higher than diet 1. The nutritional values in diets 1 and 2 were the same because isoenergetical amount of dextrin was reduced for the supplemented $\alpha$-starch in diet 2. Therefore, the superior performances of the fish fed diets 2 and 3 to diet 1 could not be attributed to the nutritional improvements of the diets judging from merely a $5 \%$ inclusion level of these materials. In addition, although no examination was conducted on gastric evacuations in this study, the poorer performances of flounder fed the diet containing $\mathrm{CMC}$ are not considered to be caused by the accelerated stomach passage because the total amount of CMC and cellulose in both diets 1 and 2 were almost the same (Table 1).

We demonstrated in this study that in vitro proteolitic enzymes' activities of flounder, especially the activity of trypsin-like in the intestine were decreased by dietary CMC. Considering the lower activities of in vitro experiments in this study, the concentrations of the proteolitic enzymes in epithelial tissues of digestive tracts would be decreased by $\mathrm{CMC}$, and $\mathrm{CMC}$ would inhibit the secretions and/or syntheses of proteolitic enzymes. Thus, it seems that the decreased enzymes', activities in flounder directly affected the protein digestion and caused reduced protein and energy retentions, and weight gain as a consequence. As Takii et al. examined on eel Anguilla japonica, ${ }^{23)}$ further examinations on the digestive enzyme activities in digesta would more clearly explain the relationship between the digestibility of protein and the activities of proteolitic enzymes.

In tilapia, digestibilities of the diets per se were reported to slightly decrease as CMC in the diets increased." However, the digestibilities of the nutritive portions of the diets excluding CMC seem to be slightly improved. Similar phenomenon was observed by Hilton et al. in rainbow trout fed diets with graded levels of cellulose. ${ }^{11)}$ Therefore, CMC in the tilapia diets was not considered to inhibit digestive enzymes' activities in contrast with Japanese flounder, but to adversely cause rapid absorptions of the nutrients by the accelerated stomach passages, and poorer performances in consequence. Thus, it would be concluded that CMC affected the performances in tilapia ${ }^{3)}$ and red sea bream ${ }^{1)}$ by changing stomach passage speed, and in flounder by inhibiting proteolitic enzyme activity. However, the factors of the different effects of dietary CMC on these three species could not be specified.

Lipase activities in the stomach and intestine of flounder were lower compared with those of the fish such as yellowtail Seriola quinqueradiata and eel reported by Morishita et al., using the same method as in this study for measur- 
ing the lipase activity. ${ }^{24)}$ This finding would support the phenomena that the specific protein sparing effect by the supplementation of dietary oil to flounder diets was not observed $^{25)}$ and that flounder did not accumulate much fat in muscles. ${ }^{20}$

When nutritional values of some ingredients such as alternative protein sources are evaluated by growth and feed efficiency as indexes, antinutritional factors derived from the other ingredients should be avoided. In the present study, CMC proved to be unsuitable as a binder for fingerling flounder diets because it inhibited proteolitic enzymes' activities and caused poorer growth and feed performances. Accordingly, other binders such as wheat gluten and $\alpha$-starch are recommended to be used in fingerling flounder diets for the nutritional studies.

Acknowledgements We expressed our gratitude to the staffs of Nanseicho Fish Seed Center, for their providing the test fish.

\section{References}

1) K. Morita, M. Furuichi, and Y. Yone: Effect of carboxymethylcellulose supplemented to dextrin-containing diets on the growth and feed efficiency of red sea bream. Nippon Suisan Gakkaishi, 48, 1617-1620 (1982).

2) M. Furuichi, K. Morita, and Y. Yone: Effect of carboxymethylcellulose supplement on the absorption of dietary nutrients and on the levels of blood sugar and plasma amino nitrogen. Nippon Suisan Gakkaishi, 49, 1367-1370 (1983).

3) S. Y. Shiau, H. L. Yu, S. Hwa, S. Y. Chen, and S. I. Hsu: The influence of carboxymethylcellulose on growth, digestion, gastric emptying time and body composition of tilapia. Aquaculture, 70, 345-354 (1988).

4) S. Y. Shiau and C. C. Kwok: Effect of cellulose, agar, carragenan, guar gum and carboxymethylcellulose on tilapia growth. World Aquaculture, 20, 60 (1989).

5) T. Yamamoto, P. Marcouli, T. Unuma, and T. Akiyama: Utilization of malt protein flour in fingerling rainbow trout diets. Fisheries Sci., 60, 455-460 (1994).

6) M. L. Anson: The estimation of pepsin, trypsin, papain, and cathepsin with hemoglobin. J: Gen. Physiol., 22, 79-89 (1939).

7) B. Hagihara: Proteolitic enzyme, in "Method for Enzyme Investigation" (ed. by Akabori), Vol. 2, Asakura-Shoten, Tokyo, 1956, pp. 237-246 (in Japanese).

8) O. H. Lowry, N. J. Rosebrough, A. L. Farr, and R. J. Randall: Protein measurement with the Folin phenol reagent. J. Biol. Chem., 193, 265-275 (1951).

9) Y. Yamamura and K. Ogura: Hydrase, in "Biochemistry II" (ed. by Japan Chem. Soc.), Vol. 24, Maruzen, Tokyo, 1958, pp. 231247 (in Japanese).

10) D. F. Leary and R. T. Lovell: Value of fiber in production-type diets for channel catfish. Tans. Amer. Fish. Soc., 2, 328-332 (1975).

11) J. W. Hilton, J. L. Atkinson, and S. J. Slinger: Effect of increased dietary fiber on the growth of rainbow trout (Salmo gairdneri). Can. J. Fish. Aquat. Sci., 40, 81-85 (1983),

12) O. B. Dioundick and D. I. Stom: Effect of dietary $\alpha$-cellulose levels on the juvenile tilapia, Oreochromis mossambicus (Peters). Aquaculture, 91, 311-315 (1990).

13) J. Anderson, A. J. Jackson, A. J. Matty, and B. S. Capper: Effects of dietaty carbohydrate and fibre on the tilapia Oreochromis niloticus (Linn.). Aquaculture, 37, 303-314 (1984).

14) P. J. Bromley and T. C. Adkins: The influence of cellulose filler on feeding, growth and utilization of protein and energy in rainbow trout, Salmo gairdneri Richardson. J. Fish Biol., 24, 235-244 (1984).

15) D. J. Grove, L. G. Loizides, and J. Nott: Satiation amount, frequency of feeding and gastric emptying rate of Salmo gairdneri. $J$. Fish Biol., 12, 507-516 (1978).

16) M. W. Flowerdew and D. J. Grove: Some observations of the effects of body weight, temperature, meal size and quality of gastric emptying time in the turbot, Scophthalmus maximus (L.), using radiography. J. Fish Biol, 14, 229-238 (1979).

17) M. Jobling: Dietary digestibility and the infuence of food components on gastric evacuation in plaice, Pleuronectes platessa L. J. Fish Biol., 19, 29-36 (1981).

18) S. Holt, R. C. Heading, D. C. Carter, L. F. Prescott, and P. Tothill: Effect of gel fibre on gastric emptying and absorption of glucose and paracetamol. Lancet, i, 636-639 (1979).

19) K. Ebihara, R. Masuhara, and S. Kariyama: Major determinants of plasma glucose-flattening activity of a water-soluble dietary fiber: effects of konjac mannan on gastric emptying and ultraluminal glucose-diffusion. Nutr. Rep. Int., 23, 1145-1156 (1981),

20) A. R. Leeds, D. N. L. Ralphs, F. Ebied, G. Metz, and J. B. Dilawari: Pectin in the dumping syndrome: reduction of symptoms and plasma volume changes. Lancet, i, 1075-1078 (1981).

21) S. E. Schwartz, R. A. Levine, A. Singh, J. R. Scheidecker, and N. S. Track: Sustained pectin ingestion delays gastric emptying. Gastroenterology, 83, 812-817 (1982).

22) H. J. Ehrlein and J. Prove: Effect of viscosity of test meals on gastric emptying in dogs. Q. J. Exp. Physiol., 67, 419-425 (1982).

23) K. Takii, S. Shimeno, M. Takeda, and S. Kamekawa: The effect of feeding stimulants in diet on digestive enzyme activities of eel. Nippon Suisan Gakkaishi, 52, 1449-1454 (1986).

24) T. Morishita, H. Noda, M. Kitamikado, T. Takahashi, and $S$. Tachino: On the activity of the digestive enzymes in cultured fish. $J$. Fac. Fish. Univ. Mie, 6, 239-246 (1964) (in Japanese).

25) K. Kuroki: Aquaculture of Japanese flounder using formulated feeds. Youshoku (an extra edition), 149-153 (1986) (in Japanese).

26) M. Sato, R. Toshinaka, T. Nishinaka, H. Morimoto, T. Kojima, Y. Yamamoto, and S. Ikeda: Comparison of nutritive components in meat of wild and cultured bastard halibut Paralichthys olivaceus (in Japanese). Nippon Suisan Gakkaishi, 52, 1043-1047 (1986).

27) S. Sakamoto, A. Eto, M. Furuichi, and Y. Yone: Purified test diet for yellowtail-1. Nippon Suisan Gakkaishi, 45, 1179-1183 (1979). 